\title{
What if intelligence is inheritable?
}

\begin{abstract}
A gloomy view of modern society based on the assumption that those in charge form a "cognitive élite" which is likely to be dynastic mischievously begs too many questions.
\end{abstract}

THE old chestnut of the social connotations of the hereditary components of intelligence (as measured by Intelligence Quotient, or IQ), has resurfaced again in the United States. The occasion is the impending publication of a book, The Bell Curve: Intelligence and Class Structure in American Life (Free Press, New York, 1994), by Charles Murray and the late Richard Herrstein, a Harvard psychology professor. Last week the New Republic, regarded as a bastion of liberal opinion which nevertheless has a healthy distaste for political correctness, published an article summarizing the argument of the book together with a sheaf of often vitriolic expressions of dissent that will ensure that the months ahead will be filled with spuriously heated arguments.

When there are so many other things to argue about, that is a great misfortune. There are several things to say, not the least of which is that there should be no restraint on the publication of solidly based data bearing on the inheritance of IQ. The second is to remark on the error familiar from past rehearsals of this corrosive argument, that a demonstration of a genetic influence on IQ is in the broadest sense irrelevant to the determination of social policy in fields such as welfare, education and the relief of poverty. Murray and Herrstein, somewhat gleefully, have blundered into that trap with their eyes open, driven by an apocylaptic view of what lies ahead for societies like that of the United States.

Whatever may be the deficiencies of IQ as a measure of intelligence, the index is an approximation of a kind. Accordingly, it is no surprise that individuals' IQ is correlated with their social success. Murray and Herrstein make a great deal of their discovery that societies such as that of the United States are run by a "cognitive élite", but that is exactly what would be expected in a meritocracy. It is quite a different question to ask to what degree that meritocracy can be properly and prudently dynastic. There is ample anecdotal evidence, in the often gloomy records of hereditary dictatorships and family businesses, to suggest that the cognitive élite does not breed true. But that, of course, is what would be expected from a multigenic influence on intelligence, as represented by the Gaussian distribution (the 'bell curve') of measured IQ in sample populations.

Murray and Herrstein do not, of course, suppose that intelligence or IQ is simply determined by people's genes. As they must, they allow for nurture as well as nature as important influences on the IQ of grown-up people. But they go on to argue that current social policies in the United States designed to remedy the disadvantages of the children of those not belonging to the cognitive élite, loosely described as 'affirmative action', have failed in their intended consequences and should therefore be abandoned. The flaw is that the explanation may just as well be that the remedial measures so far taken are both insufficient and inappropriate.

Given the wealth of evidence in the past century of the malign effects of deprivation in the earliest months of childhood, affirmative action in recruiting young people to universities and colleges is at best a tardy palliative, which is not to say that it should be abandoned (as Murray and Herrstein ask). Moreover, the provision of welfare foodstamps to the mothers of deprived children (a US practice) may be entirely insufficient to offset the other sources of deprivation in a child's emotional and intellectual environment. In short, the conclusion of the data Murray and Herrstein have assembled could just as well be that there is an urgent need to find better ways of ridding young children of the cramping effects of deprivation, not simply for its own sake but for the intellectual strength of the society of which they will become a part.

Indeed, that is not a sufficiently prescriptive way of putting it. The document on which Murray and Herrstein have laboured (by Murray's account, for eight years) will be welcomed by many of its readers for its illiberal conclusions, but the argument deserves to be turned on its head. If IQ is so convincingly correlated negatively with social disadvantage, and if at least some part of everybody's IQ is determined by nurture and not nature, should it not be a part of all governments' ambition to relieve the effects of social disadvantage and so make the best of their people's intellectual potential? The cognitive élite, at least, should recognize the force of that argument.

\section{Europe after Finland}

The European Commission must exert itself in matching cultural diversity with economic unity.

THE outcome of last Sunday's referendum in Finland on membership of the European Union (EU) will improve the chances that there will be 16 members next year. The vote (which has to be confirmed by a two-thirds majority of the Helsinki parliament) follows a similar result in Austria last June, but its immediate importance will be its effect on opinion in Sweden (to be tested by referendum on 13 